\title{
CDISC SDTM Diabetic Kidney Findings About Test Code Terminology
}

National Cancer Institute

\section{Source}

National Cancer Institute. CDISC SDTM Diabetic Kidney Findings About Test Code

Terminology. NCI Thesaurus. Code C129940.

Terminology associated with the diabetic kidney disease findings about test code codelist of the Clinical Data Interchange Standards Consortium (CDISC) Study Data Tabulation Model (SDTM). 